Abstracta Iranica Abstracta Iranica

Revue bibliographique pour le domaine irano-aryen

Volume 23 | 2002

Comptes rendus des publications de $\mathbf{2 0 0 0}$

\title{
« East Greek or Levantine? Band-Decorated Pottery in the Levant during the Achaemenid Period ». Transeuphratène 9, pp. 83-113.
}

\section{Astrid Nunn}

\section{(2) OpenEdition}

Journals

Édition électronique

URL : http://journals.openedition.org/abstractairanica/35195

DOI : 10.4000/abstractairanica.35195

ISSN : 1961-960X

Éditeur :

CNRS (UMR 7528 Mondes iraniens et indiens), Éditions de l'IFRI

Édition imprimée

Date de publication : 15 mai 2002

ISSN : 0240-8910

Référence électronique

Astrid Nunn, « « East Greek or Levantine? Band-Decorated Pottery in the Levant during the

Achaemenid Period ». Transeuphratène 9, pp. 83-113. », Abstracta Iranica [En ligne], Volume 23 | 2002,

document 40, mis en ligne le 08 février 2010, consulté le 25 septembre 2020. URL : http://

journals.openedition.org/abstractairanica/35195; DOI : https://doi.org/10.4000/abstractairanica.

35195

Ce document a été généré automatiquement le 25 septembre 2020.

Tous droits réservés 


\title{
« East Greek or Levantine? Band- Decorated Pottery in the Levant during the Achaemenid Period ». Transeuphratène 9, pp. 83-113.
}

\author{
Astrid Nunn
}

Dans l'euphorie des premières trouvailles grecques au Proche Orient, plusieurs groupes d'objets furent d'abord tenus pour grecs avant d'être réinterprétés comme production locale (voir les graffitis «grecs» puis phéniciens et araméens, F. Bron - A. Lemaire, Inscriptions d'Al-Mina, Atti del Primo Congresso Internazionale di Studi Fenici e Punici, 1983, pp. 677-686. Cf. aussi les «lécythes" grecs d'al-Mina devenus des cruches locales...). Tel est le destin de cette céramique décorée de bandes qui ressemble à de la céramique grecque de l'est. L'A. commence par une revue de la céramique grecque importée en Syrie et au Liban dès le $8^{\mathrm{e}} \mathrm{s}$. puis il dresse la liste de la céramique à bandes trouvée en Orient. La terre, la glaçure et même les formes divergent légèrement et indiquent indubitablement que cette céramique fut fabriquée en Orient. L'hypothèse déjà émise par Coldstream et Stucky est ainsi confirmée dans cette étude sérieuse.

INDEX

Thèmes : 3.0. Généralités 


\section{AUTEURS}

\section{ASTRID NUNN}

Université de Munich (Allemagne) 